Original Article

Artigo Original

Caroline Lopes Barbosa ${ }^{1}$

Cristiana Beatrice Lykouropoulos ${ }^{2}$

Vera Lúcia Ferreira Mendes ${ }^{1}$

Luiz Augusto de Paula Souza ${ }^{1}$

Keywords

Mental Health Services

Public Health

Humanization of Health Care

Speech-Language-Hearing Sciences

Descritores

Serviços de Saúde Mental

Saúde Pública

Humanização da Assistência

Saúde Mental

Fonoaudiologia
Correspondence address:

Caroline Lopes Barbosa. End: Rua:

Bartolomeu Paes, 318. Vila Anastácio. São

Paulo - SP CEP: 05092-000. Brazil.

E-mail: carolinelopesb@gmail.com

Received: August 15, 2019.

Accepted: January 14, 2020.

\section{Clinical listening, Mental Health Professionals and Speech-Language Pathology: experience in the Child and Adolescent Psychosocial Care Center (CAPSij)}

\author{
Escuta Clínica, Equipe de Saúde Mental e \\ Fonoaudiologia: experiência em Centro de \\ Atenção Psicossocial Infantojuvenil (CAPSij)
}

\begin{abstract}
Purpose: The speech therapy practice in mental health is questioned by the challenge of producing shared care strategies to, above all, expand the conditions and the communicational repertoire, the discursive and social circulation of people with mental suffering. Objective of this study was to identify the perception of clinical listening in professionals of Child and Adolescent Psychosocial Care Center (CAPSij), specifying the role of speech therapy in the care and listening of patientes. Methods: This is a participatory and dialogical research. A discussion group was used to collect data. Results: were grouped in the following categories: listening conception; listening and working process; listening effects; speech therapy and clinical listening. These professionals think of clinical listening as a central device for mental health care. The clinical listening favors reflection on the bio psychic dynamics of healthcare. It was observed contributions of speech therapy in intra and interinstitutional scopes, in the clinical-therapeutic work of the health professionals, patients and relatives. The speech therapist's skills and knowledge about organic aspects of child development in the opinion of professionals enhance clinical listening. Conclusion: It was concluded that without teamwork, care in CAPSij would not happen in a qualified way under the public health policies: Psychosocial Care Network (PSCN) and Unified Health System (SUS) frameworks. The clinical listening is a condition of possibility of the care offered by the professionals.
\end{abstract}

\section{RESUMO}

Objetivo: A prática fonoaudiológica na saúde mental é interrogada pelo desafio de produzir estratégias compartilhadas de cuidado para, sobretudo, ampliar as condições e o repertório comunicacional, a circulação discursiva e social de sujeitos em sofrimento mental. O objetivo deste estudo foi identificar a percepção sobre escuta clínica de uma equipe de Centro de Atenção Psicossocial Infantojuvenil (CAPSij), especificando a função da fonoaudiologia no cuidado e na escuta dos casos. Método: Trata-se de pesquisa participativa e dialógica. Utilizou-se grupo de discussão para coleta de dados. Resultados: estão agrupados nas categorias: conceituação de escuta; escuta e processo de trabalho; efeitos da escuta; fonoaudiologia e escuta. A equipe pensa a escuta clínica como dispositivo central nos cuidados em saúde mental. A escuta clínica favorece a reflexão acerca de dinamismos biopsíquicos do cuidado em saúde. Observou-se contribuições da fonoaudiologia em camadas intra e interinstitucionais, assim como no trabalho clínico-terapêutico da equipe de saúde, dos usuários e familiares. As competências e conhecimentos do fonoaudiólogo sobre aspectos orgânicos do desenvolvimento infantil, na opinião dos profissionais, potencializam a escuta clínica. Conclusão: Conclui-se que, sem o trabalho em equipe, o cuidado no CAPSij não aconteceria de forma qualificada sob os marcos da Rede de Atenção Psicossocial (RAPS) e do Sistema Único de Saúde (SUS). A escuta clínica é condição de possibilidade do cuidado ofertado pela equipe.

Study conducted at: Programa de Estudos Pós-graduados em Fonoaudiologia (Doutorado) da Pontifícia Universidade Católica de São Paulo - PUC-SP - São Paulo (SP), Brasil.

${ }^{1}$ Pontifícia Universidade Católica de São Paulo - PUC-SP - São Paulo (SP), Brasil.

${ }^{2}$ Secretaria Municipal de Saúde de São Paulo - São Paulo (SP), Brasil.

Conflict of interest: nothing to declare.

Financial support: Coordenação de Aperfeiçoamento de Pessoal de Nível Superior - Brasil - CAPES PROSUP 88887.151934/2017-00. 


\section{INTRODUCTION}

The Psychosocial Care Network (PSCN) challenges the practice of its professionals and draws its own institutional and clinical outlines, arising from the anti-asylum movement and its unfolding in health policies and practice.

Such outlines aim to overcome the hospital-centered mindset - focused on medicalized care and institutionalized isolation - and build health care capable of welcoming and caring for people with mental disorders. The effort is due not only to the psychopathological dimensions involved but also to the amplitude of the social and (inter)subjective conditions that cause, maintain, and/or intensify the subjects' psychic suffering in their contexts, lifestyle, and history (personal, family, social).

It is in this aspect that the PSCN undertakes the Broadened Clinic as one of its guidelines in mental health care, summoning its professionals to make their disciplinary knowledge available in a clinic centered on the suffering subjects, on listening to the subject and the experiences and events that constitute who they are - either sustaining or not their subjectivity. These are the processes with which people develop (or try to develop) their individuality, both for themselves and for the others.

In the perspective of the Broadened Clinic, listening is defined as the investigation of the reasons that led to the patients' disease, as well as their feelings and response to the symptoms and suffering, in order to understand the disease and become (co)responsible for producing their health in the care process ${ }^{(1)}$.

This concept of listening here draws near the one given it by psychoanalysis; in our words: "It is the professional attention at the same time sensitive and technical, that is based on manifested content (complaints and symptoms) to understand and develop, along with the patient, the latent contents and demands underlying the visible aspects of the suffering presented to the clinician. These are somatic and/or psychic contents - experiences and manners to deal with life and health - that lead to the disease and maintain or intensify the symptomatology. Not surprisingly, Freud ${ }^{(2)}$ stated that 'it should not be forgotten that what is listened are mostly things whose meaning will only be identified posteriorly"'.

The perspectives of the Broadened Clinic were outlined by the National Humanization Policy - NHP (2009), facing the fragmentation in the field of health of both the work process and the still dominant tendency to focus on specialization in professional training and practice at the Public Health Care System (SUS, its Portuguese abbreviation).

The goal of the NHP included valuing the integrated intercrossed disciplinary approaches in the search for a more effective manner to handle the complexities of the work in health care. In this regard, clinical listening is a means to lift the patients to the position of protagonists, opening the most strictly disciplinary positions of the professionals to the heteroclite and manifold character of the health/disease process.

These considerations suggest that, besides the technical and procedural dimensions, the work in health care is also necessarily dialogical, as it intersects the varied knowledge not only of the professionals but also the patients, regarding their lives and health/disease processes.

Campos et al..$^{(3)}$ clarify that the practice of the Broadened Clinic [...] presupposes the existence of public settings, where the professionals as a team put their skills into practice, and together analyze the issues and intervene on them, reflecting on the effects of their practices regarding what is happening in the relationship within the team and between the team and the patients, thus collectively debating about it. (p. 991)

Both the teamwork and clinical listening are pillars of the PSCN clinic. The Psychosocial Care Centers (PSCC), in this sense, develop health care dealing with the cases through reference teams, in the attempt to consider them collectively and interact with the health territory.

For the speech-language-hearing sciences, the reflection on the bases and meanings of its belonging to the field of health implies in various things, including the concepts of language (their aim), subject, and clinic that can be settled there, to ground and define practical approaches on how to work in the different areas of the PSCN health care.

The speech-language-hearing practice in mental health is challenged to produce shared health care strategies so it will, above all, broaden the means, the communicational repertoire, the discursive and social circulation of the subjects in mental suffering. The professionals at the child-youth Psychosocial Care Center (cy-PSCC), where this research was conducted, perceive in the patients' language difficulties one of the main hindrances to the psychosocial care and social interaction.

The issue for the speech-language-hearing practice, then, is to contribute with clinical knowledge and expertise regarding aspects and dimensions related to human communication and its eventual disorders, and to do so in combination with the knowledge of the others in the cy-PSCC team, in agreement, grounding and building practical approaches of health care for people with mental disorders, as well as structuring clinical listening to the cases to develop and follow up the Unique Therapeutic Projects (UTPs).

The speech-language-hearing science is thus drawing nearer the field of mental health grounded on the concepts of "core" and "field" proposed by Campos ${ }^{(4)}$. According to the author, "the core outlines the identity of a field of knowledge and professional practice, whereas the field is a space with imprecise limits, where each discipline and profession seeks support from the others to accomplish their theoretical and practical tasks" (op. cit., p. 220). The issue is not to abdicate from the creative flow of each core, but to create an intersection connecting them; to manage and interfere in the disciplinary cores, making the various fields of knowledge and professional practices at the SUS to thrive $\mathrm{e}^{(5)}$.

As it has been made clear, the field of interest here is mental health - the field of knowledge and clinical practices - and the core is that of speech-language-hearing, the discipline responsible for the studies and clinical care of what is called human communication disorders. Human communication is understood, in the words of Souza(6), as: 
Function and potential of the language, in the sense of an inevitable desire to communicate with others and be welcomed by them, which is an unavoidable condition for the person to rise and develop. (p. 35-6)

Almeida $^{(7,8)}$ points out that the speech-language-hearing therapist, integrating the PSCC teams, besides detecting and treating speech-language-hearing alterations, must also "stimulate the communication and discursive circulation between patients, and between them and the family, professionals and society, intensifying the uses of language (verbal and nonverbal), and shedding light on the importance of communication" in rehabilitating the functioning of language in people with mental disorders.

The speech-language-hearing therapist is one of the professionals in the minimal cy-PSCC team makeup. However, it is known that still only a few of them work in these services.

Expanding the presence of speech-language-hearing in mental health also requires a process inside the disciplinary core - to think their job in terms of mutual relationship with a team and the field of mental health, besides the rehabilitation of speech, hearing, voice, and orofacial motor disorders and symptoms. This suggests more transit for knowledge and clinical strategies, other than those usually approached by speech-language-hearing therapists. That means being open and flexible to rethink the disciplinary therapeutic process based on listening to the uniqueness and circumstances of the psychic and social suffering of the mental health patients, as well as in relation to the conditions and characteristics of the services where the speech-language-hearing therapist works.

From this standpoint, the speech-language-hearing therapist is invited to depart from a supposed dichotomy between communication disorder rehabilitation and psychosocial care and move toward considering language as common ground, the object of all cores of knowledge in the field of mental health, although differently approached by each discipline.

In other words, there is a common ground where the specialties intercross (social, biopsychic, and language). These are areas where they meet and build together as health professionals; therefore, they are a support for teamwork, clinical listening, and the interdisciplinary health care process.

For this reason, dealing with the mental patients' language problems will make sense if the language is understood in its condition of a human process, operating as a differential signal game, engendering "differences in the processes of uniqueness and subjective constitution of people and groups, skirting the organic and symbolic dimensions of the human body's functioning"(6).

The eloquence and meaning are not necessarily in the patients' speech; they are also in the unspoken and in behaviors whose intelligibility is blocked by the mental disorder, either accompanied or not by a specific communication disorder.

As the speech-language-hearing sciences participate actively in this debate at the cy-PSCC and the clinical unfolding generated by it, this study aimed to identify, through clinical listening to the cases, how the health team perceives speech-language-hearing, its role in the multiprofessional work, and the health care follow-up.

\section{METHODS}

This is a descriptive case study, with a participative and dialogical approach, conducted through group debates involving social participants from a specific place - the multiprofessional team of a child-youth Psychosocial Care Center.

The participative method enables the investigation of collective representations and orientations. This establishes relationships based on trust and reciprocity between research authors and participants in the study of specific social epiphenomena.

Hence is the reason for our methodology: The possibility of getting in touch with the real situation in a specific place and with its true actors, to answer the questions in the research.

On the occasion, the team counted with 26 workers: team manager, pharmacist, pharmacy technician, workshop leader, and physical educator; two nurses, two social assistants, two speech-language-hearing therapists, two community assistants, and two psychiatrists; three occupational therapists; four nurse assistants, and four psychologists. Of these professionals in the team, 21 voluntarily agreed to participate in the research and signed the informed consent form (ICF). There were no exclusion criteria.

In a general meeting, the professionals were instructed about the stages and procedures in the research, which complied with the norms applicable to human research. The study was approved by the Ethics Committee of the Pontifícia Universidade Católica de São Paulo under evaluation number 2.069.413 and was registered in the Plataforma Brasil under CAAE: 55931716.4.0000.5482.

Four discussion group meetings were conducted with the cy-PSCC team from August to October 2017.

\section{Discussion group}

The discussion group is an instrument that establishes a route to access and partially reconstruct different social and public environments. The purpose is to get in touch with epiphenomena to analyze the issues and variables during the interaction ${ }^{(9)}$.

This research procedure deals with interactive discursive processes, in which "the opinion of the group is not the sum of individual opinions, but the result of collective interactions. Each member distinctly participates, but the individual speeches result from mutual interaction"(9).

The discussion group was put into effect in four meetings and used facilitating techniques for group investigation, described in the sequence.

\section{World Café}

In the first group meeting, we had a World Café - an easyto-use technique that creates a welcoming environment for dialogue, allowing participants to collaborate and express themselves based on triggering questions. 
Studies on participative methodologies also highlight the World Café as a diagnosis and intervention technique ${ }^{(10)}$ linked to the community-based participatory research (CBPR) by its collaborative nature. In it, the researcher-participant invites the community to engage and solve problems together - the stakeholders $^{(11)}$. As a result, it is expected that the connection, participation, and debate between those involved will be broadened. The conversation environment "among café mates" favors various things, including iconographic records and summaries ${ }^{(10)}$.

In this study, the World Café was conducted by a researcherparticipant, aided by an observer. The room was adapted with four small tables, with room for up to six people at each. The participants went through all the tables in the rounds of conversation, except for the host, who remained in the same table receiving the others and summarizing the ideas they had debated at each moment during their move from table to table. Two rounds of questions were carried out:

\section{First round of questions}

- What does listening mean?

- Is listening practiced with patients and their families in the teamwork? Who listens? What is listened to? How is it listened?

- Does listening produce concrete effects in the patients' health care and their family? What effects are there?

- Does listening have effects on the professionals and team? What effects? Why?

- Is listening structured by the team? How does it happen? What makes it easier? What makes it more difficult?

\section{Second round of questions}

- What does speech-language-hearing have to do with the activation of listening by/within the team?

- Do you notice any contribution of speech-languagehearing in the work process and in the manner of listening to the patient and their family at the cy-PSCC?

\section{Fishbowl Method}

The Fishbowl Method was used in the second discussion group meeting, taking further the World Café debate. The Fishbowl Meeting is a technique used to manage group discussion in a methodical, and yet plural and democratic manner. The name fishbowl is due to the format of the activities: Some chairs form an outer circle for the group, while in the center there is a "fishbowl" (the inner circle), with fewer chairs ${ }^{(12)}$.

The format enables a growing structure in which the talk circulates, organizing one inside and one outside the fishbowl. There is a defined ethical procedure: To speak, the participant must be in the fishbowl, so the person chooses someone who is inside, tap their shoulder as a code for them to give up their seat, and then the one who was outside enters and is given the word. This situation is repeated throughout the activity, and any participant can join the debate many times.

The fishbowl is almost always part of a bigger process of dialogue and deliberation ${ }^{(12)}$ - in this case, the discussion group. The fishbowl is an encouraging technique that promotes a pleasant environment for sharing ideas, a group brainstorming in which the participants respond to one another, instead of the researcher or moderator ${ }^{(13)}$.

\section{Data analysis}

The content analysis followed that proposed by Bardin(14): - pre-analysis, with floating reading of the videos and field diary; - preparation of the material; - construction of the raw data (corpora) with analysis dimensions and directions; - treatment of the material and establishment of outlining rules to categorize and code the material.

The outlined categories and subcategories were:

- Category: Concept of listening.

- Subcategories: Who listens; Listening content

- Category: Listening in the work process

- Subcategory: Facilitating and hindering aspects

- Category: Effects of listening

- Subcategories: Effects of listening on patients and their family; Effects of listening on the team.

- Category: Contribution of speech-language-hearing in the work process.

- Subcategory: How speech-language-hearing contributes to the manner of listening.

\section{RESULTS}

The excerpts were organized in categories and subcategories because of the enunciative and dialogical character of the material. Some statements of the cy-PSCC team (selected excerpts) appeared in more than one analytical category and/ or subcategory, since, in the conversational context, certain perspectives and arguments are intersectional regarding the themes addressed. They were analyzed in the Discussion.

\section{Category: Concept of listening}

The team understands that clinical listening ranges from the opening and availability to another person to the signifying of what is listened to as a working material indispensable to the field of mental health:

Listening is the working material in child and adolescent mental health. Without listening, the cy-PSCC does not work, does not have any work, neither does welcoming ever start.

If we do not listen to the patient, we cannot intervene. The UTP is based on what we listen to. 
It is in the field of listening that the latent content is reached, promoting affection, and producing therapeutic effects.

Listening begins in the professional's interest and availability, the psychic and affective possibility [the possibility of affecting and being affected].

Listening produces positive and negative affections, which will be developed in the process.

\section{Listening is being affected.}

Listening begins in the professional's interest and availability, but also the team's psychic and affective possibility.

The cy-PSCC team points to the field of affections as a dynamic transference activated by clinical listening:

Listening is welcoming the patients and interpreting their contents and requirements to help them unfold the happenings in their life.

Listening allows the person to speak, enabling selfreflection so that they are affected by their psychic content. It means using the patient's words as an instrument for them to listen to themselves.

Listening takes place in the encounter, therefore it implies countertransference.

\section{Subcategory: Who listens}

Even though there is a consensus that listening is central, the meaning of listening seems to vary and even point to the need for reflection for the device to be more widely used, both as a therapeutic practice and in its possible institutional meanings and uses.

\section{A therapist must know how to listen.}

If we consider how public health is supposed to work, everyone should listen, from the receptionist, the janitor, to the professionals who are dealing with the cases.

The whole team listens, but there are differences, depending on the specificity.

We worry about our listening and that of others. There is a collective aspect of listening because we are the service [and the service is structured by the teamwork and by an institutional logic].

\section{Subcategory: Listening content}

In the following part, there is an emphasis on the process that transforms the literality of the contents brought by the patients and/or family with expectations and needs. It corroborates the idea that clinical listening owes to the capacity of interpreting the statements, attitudes, and behaviors, so the unspoken is listened to:

In the first place, we listen to their complaints; then we translate them into needs. The needs are not straightforward; what is presented are the patients' and family's complaints, exactly because they cannot formulate straight away their needs. We interpret the complaints to access and understand the needs (...)

We also have to listen to the potentialities. Otherwise, we only work on the disease, not on producing health.

There are contents we do not want to listen to, not to go too deep into the situation.

\section{Category: Listening in the work process}

Again, here is given the notion that listening furnishes decisive material for the work to happen, giving it quality at the same time.

Without listening, the cy-PSCC does not work, there is no material to work with. Teamwork only happens after listening.

The quality of the treatment we offer is based on listening.

Listening is a powerful intervention in health care. Listening validates speech, feelings, and thought. When we listen, we are caring. We do not use some other sophisticated technology. Listening is our precious instrument. At least for the psychologist, listening is everything we can do to build rapport with the patients: listening and qualifying that listening.

If we think about public health, on how it is structured, listening must happen from the beginning (...) to the discharge.

Listening takes place at many moments of our work: in the team meetings, in the clinic supervision (that we do not have anymore!), in welcoming patients and family, in the different health care modalities.

Listening is welcoming the patient and interpreting the contents for them to develop the happenings in their life. Listening is also a setting.

The look broadens the path, and listening is potentialized in the exchange of knowledge. The look improves, and listening is refined. In this process, we broaden our horizons. The psychologist is not only a psychologist, for they have other practices and knowledge as well. 


\section{Subcategory: Facilitating and hindering aspects}

The team invests in articulating knowledge as a potential to solve the issues brought by the patients and the family.

No knowledge is above the other. The multiprofessional team articulates knowledge to solve the issues the family and patients bring.

Nevertheless, tensions are perceived between the team's listening and the anguish in defining actions for certain care processes:

The problem is when we do not know how to respond to what we have listened.

The moments of uncertainty are the toughest for us to listen to each other as a team.

Depending on how we are affected and take on the case, there is a risk of remaining alone as the patient's reference professional.

There is the difficulty of expressing ourselves, of speaking up, the fear of how our words will be received.

I have already given up speaking in our meetings. When I speak up, someone interrupts me or control me, saying "Stop!". I know I have not studied that much, but it should be a team process.

This last excerpt was spoken by a community assistant, position occupied with technical training (high-school level), similar to a therapeutic companion under the supervision of a professional with a bachelor's degree. The above excerpts point to difficulties in the development of some therapeutic projects as a team.

\section{Category: Effects of listening}

\section{Subcategory: Effects of listening on patients and their family}

Here, listening is seen as a device to promote protagonism in the families as they fight for their rights.

Listening empowers the parents, who come to know their rights and fight for them.

Listening has visible effects on the family dynamics, on their understanding of the child's difficulties, and their relationship.

\section{Subcategory: Effects of listening on the team}

Without quality listening the work in health care tend to lose its quality:

The quality of the treatment we offer is affected by listening.

Listening means being affected by what the other says. It is not in every case that we will be affected but giving legitimacy to the patients' suffering and words is in itself listening.

On the other hand, when listening affects the therapist and the team, the therapeutic bond is more consistent, with therapeutic effects:

Effective listening has visible effects on the family dynamics, on their understanding of the child's difficulties, and their relationship.

The team states also that listening summons the disciplinary cores to play in the field of mental health.

I believe listening in speech-language-hearing is essential to the work with the patients. It really is! The parents are eager to speak. But among the professionals and in the team, there is no difference.

The possibility of using each other's knowledge of listening and caring for the patient is important. It is necessary to understand the differences in the psychologist's, the nurse's perception, as well as the other professionals', in establishing our work.

The whole team listens, but there are differences, depending on the specificity.

\section{Category: Contribution of speech-language-hearing in the work process}

The capacity to mediate communicative processes in the face of complex situations is also attributed to the speechlanguage-hearing therapist:

The population we most receive are those with autism spectrum disorder (ASD), in whom the communication difficulties are too intense. Since the child is not able to communicate, sometimes getting aggressive, the speechlanguage-hearing therapist is the one who can help.

The speech-language-hearing therapist interprets the speech affected by a disorder. 
The speech-language-hearing therapist's work is essential to the cy-PSCC because the main complaint regarding the children when they arrive here is their delayed speech.

We acknowledge the speech-language-hearing therapist's specific contribution to the work process, especially when the child has already been assessed by other professionals and the team is in doubt about the diagnosis. The speech-language-hearing therapist helps to define whether the difficulty is organic, symbolic, or behavioral.

Their specific contribution is the speech-languagehearing therapist's careful assessment to help in the differential diagnosis as a team.

In some statements, the speech-language-hearing therapist's knowledge of certain organic aspects of child development suggests that the relationship between the core (speechlanguage-hearing) and the field (mental health) is a composition that enables them to consider biopsychic dynamisms, which can generate better decisions regarding the patients' care.

Speech-language-hearing offers technical support about the case to the team, helping care for the patient and discuss the cases with the network [of services the patient attends].

Speech-language-hearing has specific instruments that contribute to our look at the organic aspects, to assess language, oral issues, speech, and hearing.

Listening was different when I cared for or welcomed a patient along with the speech-language-hearing therapist because she has a refined look at neuropsychomotor development.

The psychologist only goes so far; beyond that, it is the speech-language-hearing therapist's specific area. Only they will not in detail what to do with delayed speech, dysphagia, and other specific issues.

It was noted that the body and psychism seem to be fertile land to think about listening as an arena for issues of the field of mental health.

(...) I recall a boy who was referred to our service as having an eating disorder; he only took liquids. In the assessment process, the speech-language-hearing therapist asked him to open his mouth, and there was not room enough for solids. The boy had huge tonsils! It was not an eating disorder due to psychological issues, but an organic blockage. If it were not for the speech-language-hearing therapist, I, as a psychologist, would not have asked him to open his mouth. I thought it was just an emotional issue.
Some families ask to see the speech-language-hearing therapist at the cy-PSCC because their understanding is that delayed speech is the child's only difficulty. But, during the assessment, we also observe psychosocial and behavioral issues, to name some. The speechlanguage-hearing therapist develops the care.

When assessing a child with auditory or language alterations, we quickly call for the speech-languagehearing therapist because she has a differentiated listening to language.

My listening to the children changed a lot after I started working with a speech-language-hearing therapist because she sees the child differently, integrating to the psychic the organic aspects involved in language.

The speech-language-hearing therapist's listening broadens how the team sees the patients and their family, interfering in the multiprofessional intervention.

\section{Subcategory: How speech-language-hearing contrib- utes to the manner of listening}

Clinical listening is considered by the whole team as a common ground in the field of mental health. The disciplinary cores contribute with technical refinements.

Listening does not belong only to our field (speechlanguage-hearing). We qualify and develop listening in the setting where we are.

Within a team with a transdisciplinary approach such as we have in the cy-PSCC, the speech-language-hearing therapist activates the listening and the specialized look at language, oral-motor function, and hearing.

The speech-language-hearing therapist gives technical support about the case to the team, helping in the care for the patient and the case discussions with the health care network.

It is based on this concreteness that the speech-languagehearing therapist seems to work in the team and in the development of listening to the patients and the team.

The speech-language-hearing therapist activates the listening in the team contributing with a differentiated and broadened look.

I liked it very much when the speech-language-hearing therapist joined the group and said: "This child has so and so difficulty; you can play and work with them this way"!

I have learned a lot with the speech-language-hearing therapist. I understood some primary difficulties 
children have, regarding swallowing, language, and communication because she shared her knowledge with us.

\section{DISCUSSION}

The cy-PSCC, as a device to invert the hospital-centered asylum mindset, is grounded on the interdisciplinary work of multiprofessional teams, without institutionalizing the patients. It is guided by the mindset of working as part of a network, recognizing the patients as people who have rights, seeking to make them protagonists of their stories, and health care.

The investigated cy-PSCC presents itself in this mindset, and clinical listening appears in the words of its professionals as inherent to the work process in mental health.

The cy-PSCC team made use of listening and made it central when speaking of their work, placing clinical listening on the level of their affections. By the way, affection is a term that appears oftentimes in the team's speech. Employing it is sometimes related to feelings triggered by the relationship with the cases; at other times, it indicates changes in the way the patient is perceived and understood.

The philosopher Baruch Spinoza $(1632 / 1677)^{(15)}$ conceptualizes affection as a condition of possibility of living bodies, a bivalent power: affecting other bodies and being affected by them. The affections are forces capable of changing the previous state of a body, causing differential marks in its trajectory: new modes of existence, other ways of being.

It is known that affective power recalls an essential condition of the clinical practice: to instigate differentiation processes in the patients, as a means of facing their needs and working them out. Naturally, the affective process supposes effects on the patient and therapist, in the same sense given them by the psychoanalytic concepts of transference and countertransference, respectively: updating and developing areas of the patient's psychic contents, provoked by the therapist and identified with them; and updating psychic contents of the therapist when affected by the patient's content. In psychoanalysis, countertransference must be worked and controlled by the analyst not to cause undesired effects on the patient's analytical process.

The patients' mental disease and suffering can be seen by them and their relatives as a personal problem, disarranging life. It could be admitted, along with Benevides and Passos ${ }^{(16)}$, that by destabilizing this situation, clinical listening (associated with other clinical devices) promotes productive processes in the clinical practices and the patients' and family's self-care, opening health care to the development of (inter)subjective, contextual, and social determinations of health impairments. The words of the team seem to go in that direction.

When "who listens" is investigated, a certain ambiguity is noticed. Some speeches are nonspecific and tend to commonsense, whereas others recognize the listening knowhow as a result of professional competencies developed so that listening effectively has clinical-therapeutic and institutional dimensions.

Furthermore, there is also the perception that, although listening has specificities in each specialty, there are collective effects, a kind of team listening, born from the combined effort, and the relationships between the team's knowledge and practices.

Two other notions crucial to the field of clinical listening arise in the team's conversation: acknowledging that it is necessary to listen to potentials of health in the suffering; and admitting that there are limits to the team regarding contents one cannot bear listening or cannot uphold.

Concerning the limits of listening, it was observed that the team attributes the impossibility of getting in touch with some of the patients' contents to the intensity of demands the patients bring up, as seen in the words of the team: "There are contents we do not want to listen to, not to go too deep into the situation". It is evident that this is a relational field permeated by crises, as well as stories of institutionalizations and lives permanently affected by suffering, anguish, and in more severe cases, the psychic devastation caused by the acuteness of the symptoms, and relational and social effects caused by them.

The team acknowledges that listening permeates the patient's whole trajectory ever since they arrive at the service, which is also present in all the devices operated by the team.

On the team's perspective, clinical listening is characterized as a welcoming setting.

Understanding that listening is modulated and refined by the team - as the different professional knowledge and that of the patients intersect - reiterates the idea that the interprofessional interactions can configure its meanings and interdisciplinary knowledge, which requalifies each professional's training and practice.

Each cy-PSCC outlines, according to the institutional therapeutic project, the work arrangements to operationalize the UTPs with the patients. The case's reference professional is the one responsible for monitoring the care for the patient and their family. However, the risk of feeling lonely sometimes lingers, despite the therapeutic arrangements.

On the other hand, there are hints of limits to listening due to undesirable hierarchies.

Everyone's words should be listened to, as a colleague said: "It should be a team process". Nevertheless, the professionals who have not attended university feel submitted to a hierarchical institutional culture, in which the professional with a bachelor's degree, either intentionally or not, poses themselves as superior.

The team notices that their listening produces effects on the patients, who respond with their look, in the symbolic play, and/ or through speech. The protagonism they perceive in the patients is different from the one they notice in the relatives - as read in the excerpt: "Listening empowers the parents, who come to know their rights and fight for them". Empowering the parents is understood as providing the family settings where they are listened to, as well as conditions and opportunities for them to acquire new repertoires that positively impact the quality of the family relationships, with their children and the community. In the team's words: "Listening has visible effects on the family dynamics, on their understanding of the child's difficulties, and their relationship".

Regarding the effects of listening on the team, it is interesting to notice the understanding that encountering another person may or may not affect the one who is clinically listening. That is a fact that cannot be fully controlled by the professional but 
should be the object of the professional's and team's reflection, in an effort to understand the difficulties in building rapport and following through to overcome the issue. However, sometimes that is not presented as a hindrance to listening on the part of the professionals.

The team understands that speech-language-hearing actively contributes to the manner of listening to the patient, integrating the disciplinary knowledge, the therapeutic approaches, the technical support to the network for discussions and articulations in between sectors.

The differentiated listening to language, besides the capacity to consider its organic and functional aspects, encompasses the senses with which the team considers the speech-languagehearing knowledge and contributions to structuring collective listening to the cases.

Given the above, it can be stated that there is a certain insistence on the dichotomy between the organic and the psychic, which tends to place the organic relatively out of the team's reach. In this case, the specificity of the speech-language-hearing therapist plays an articulator's role. However, when one pays attention to the other person, are they not dealing with the body, and in it the psychic dimension? In other words, is not psychism a specifically human manner of body functioning? If that is so, certain dilemmas, that are still in the disciplinary basis of the health professionals' training, continue to challenge us.

\section{CONCLUSION}

The study suggests that, if it were not for the teamwork - from the standpoint of the broadened clinic-, the work at the cy-PSCC would not take place as stipulated by the PSCN and SUS frameworks.

Clinical listening is set as a condition for health care, to manage the multiplicity of factors involved in psychic disorders. Naturally, it is necessary to be available and sensitive to listen. However, if this is necessary, it is not enough for listening to fulfill its role of moving from the manifested contents to the latent ones - which makes the mediations possible, leading to the development of clinical demands. There is a technical modus operandi in listening, which produces interpretations of what is left unspoken through the literality of words, in an intrinsic relationship between the structuring of the language, psychism, and modes of relationship with other people.

The assumption of this inseparability helps develop the speech-language-hearing's belonging in mental health, putting the knowledge meant for treating communication difficulties into service in the field of mental health, collaborating with listening and care, through which the patients (and their relatives) signify, face, and overcome stigmas and sufferings occasioned by the mental disorders.

\section{REFERENCES}

1. Brasil. Ministério da Saúde. Clínica Ampliada e Compartilhada. Secretaria de Atenção à Saúde Política Nacional Humanização da Atenção e Gestão do SUS Brasília. 2009.
2. Freud S. Recomendações aos médicos que exercem a psicanálise (1912a). Imago, editor. Rio de Janeiro: Edição standard brasileira das obras psicológicas completas de Sigmund Freud, v. XII; 1976. p. 149-163.

3. Campos GW de S, Figueiredo MD, Pereira Júnior N, Castro CP de. A aplicação da metodologia Paideia no apoio institucional, no apoio matricial e na clínica ampliada. Interface - Comun Saúde, Educ [Internet]. 2014 Dec;18(suppl 1):983-95. http://dx.doi.org/10.1590/1807-57622013.0324

4. Campos GWDS. Saúde pública e saúde coletiva: campo e núcleo de saberes e práticas. Ciênc saúde coletiva. 2000;5(2):219-30. https://doi.org/10.1590/ S1413-81232000000200002.

5. Passos E, Benevides RB. A Construção do Plano da Clínica e o Conceito de Transdisciplinaridade. Psicol Teor e Pesqui [Internet]. 2000 Apr [cited 2018 Jul 16];16(1):71-9. https://doi.org/10.1590/S0102-37722000000100010.

6. Souza LA de P. Voz, corpo, linguagem. Sala Preta - J USP. 2007;7:33-7. https://doi.org/10.11606/issn.2238-3867.v7i0p33-37.

7. de Almeida BPB, Cunha MC, de Paula Souza LA. Speech Therapy and Mental Health: Service Group to Institutionalized Individuals with Mental Disorders. Rev Int Humanidades Médicas. 2015;4(2). https://doi org/10.37467/gka-revmedica.v4.852.

8. de Almeida BPB, Cunha MC, de Paula Souza LA. Características e demandas fonoaudiológicas de pacientes adultos portadores de transtornos mentais e institucionalizados em um Centro de Atenção Integral à Saúde de São Paulo. Distúrbios da Comun. 2013;25(1).

9. Weller W. Grupos de discussão na pesquisa com adolescentes e jovens: aportes teórico-metodológicos e análise de uma experiência com o método. Educ e Pesqui [Internet]. 2006 Aug [cited 2017 Apr 7];32(2):241-60. https://doi.org/10.1590/S1517-97022006000200003.

10. Bacci D de LC, Santos VMN dos, Caruso CF de M, Santos IP de O. Metodologias participativas. In: Jacobi PR, Paz MGA da, Santos IP de O, editors. Aprendizagem social no saneamento básico: metodologias para o fortalecimento do controle social. São Paulo: IEE - USP; 2015. p. 64.

11. Bulsara C, Khong L, Hill K, Hill AM. Investigating community perspectives on falls prevention information seeking and delivery: older person perceptions regarding preferences for falls prevention education using a world cafe approach. J Community Psychol. 2016 Sep 1;44(7):937-44. https://doi. org $/ 10.1002 /$ jcop. 21816

12. Knowledge Sharing Toolkit. Fish Bowl [Internet]. 2016 [cited $2018 \mathrm{Jul}$ 4]. Available from: http://www.kstoolkit.org/Fish+Bowl

13. Garrison K, Munday NK. Toward Authentic Dialogue: Origins of The Fishbowl Method and Implications for Writing Center Work. Prax A Writ Cent J. 2012;

14. Bardin L. Análise de conteúdo. 3a edição. Edições 70, editor. Lisboa; 2004. $221 \mathrm{p}$

15. Spinoza B. Ética, demonstrada segundo a ordem geométrica. Tradução do Latim: Tomas Tadeu. Belo Horizonte: Edit. Autêntica; 2009.

16. Benevides RB, Passos E. Clínica, política e as modulações do capitalismo. Lugar Comum. 2004;19-20:159-71.

\section{Authors' contributions}

$C L B$ : conception, design, data collection, data analysis and interpretation, writing of the article, critical review and approval of the version to be published; $C B L$ : data supervision and approval of the version to be published. VLFM: data supervision and approval of the version to be published; LAPS: conception, design, data analysis and interpretation, guidance, writing of the article, critical review and approval of the version to be published. 